\title{
Acute HBV Related ALF- Successful Outcome with Oral Antiviral Treatment
}

Parveen Malhotra*, Vani Malhotra, Yogesh Sanwariya, Ajay Chugh, Isha Pahuja, Akshay

Department of Medical Gastroenterology, Gynecology \& Obstetrics, PGIMS, Rohtak, Haryana, India.

*Corresponding Author: Parveen Malhotra, 128/19, Civil Hospital Road, Rohtak, Haryana, India (124001).

Received date: October 22, 2021; Accepted date: October 29, 2021; Published date: January 05, 2022

Citation: P Malhotra, V Malhotra, Y Sanwariya, A Chugh, I Pahuja, Akshay. (2022) Acute HBV Related ALF- Successful Outcome with Oral Antiviral Treatment. J Clinical Research and Clinical Trials. 5(1); DOI: 10.31579/2693-4779/069

Copyright: () 2022 Parveen Malhotra, This is an open access article distributed under the Creative Commons Attribution License, which permits unrestricted use, distribution, and reproduction in any medium, provided the original work is properly cited.

\begin{abstract}
Case report: We present a young female of fourteen years who was admitted to the hospital with short duration of Icterus, malaise, vomiting and diagnosed to be having acute hepatitis B. She went into acute liver failure as evidenced by development of hepatic encephalopathy and coagulopathy. She was managed on lines of hepatic encephalopathy along with oral antiviral treatment. She recovered successfully and was discharged after two weeks in heamodynamically stable condition. After a gap of six months, she became Hepatitis B surface (HbsAg) \& hepatitis B e-antigen (HbeAg) negative and Hepatitis B Virus DNA (HBV DNA) was undetectable with normal liver function tests. She is on regular follow up for last one year and is absolutely normal.

Conclusion: Acute hepatitis B can go into acute liver failure in $1 \%$ of cases, treatment for which includes liver transplantation and oral antiviral treatment which is especially helpful in cases who cannot afford liver transplantation, as was in our case.

Keywords: hbeag; hbv dna; hepatic encephalopathy; acute liver failure; entecavir
\end{abstract}

\section{Introduction}

Hepatitis B virus (HBV) infection rarely cause Fulminant liver failure but has a poor prognosis with high mortality rate which aggravates in presence of co-infection with hepatitis D virus (HDV). A large inoculum is associated with a shorter incubation period than with other fulminant liver failure. In contrast, a quick immune response is more closely related to the development of fulminant liver failure than to increased viral replication [1]. This means that the early turn of HbsAg to anti-HBs might be involved in the pathogenesis of fulminant liver failure [2]. The association between a mutation of $\mathrm{HBV}$ and the development of fulminant hepatic failure has already been reported [3,4]. A mutation has been described in the precore, core and protein of HBV that apparently induces hepatocyte apoptosis but it is not a prerequisite for the development of fulminant liver failure $[5,6]$. Post mortem examination evidence shows the liver suffers massive necrosis. The mutation in the precore either causes massive $\mathrm{T}$ cell activation or causes massive damage to the hepatocytes by a rapid increase of $\mathrm{HBcAg}$ [2].

\section{Case Report}

A fourteen year old female, not a known case of any chronic illness presented with history of initial prodromal symptoms for one week in form of fever, malaise, nausea followed by vomiting, development of Icterus and pruritus. She was symptomatically treated by local practioners but got no relief. After a gap of one week, she was admitted at our institute. On physical examination, the patient was conscious, cooperative, afebrile and icteric. The general physical examination revealed mild pallor and deep jaundice. The systemic examination including chest, abdomen, cardiovascular, central nervous system, ophthalmological and dermatological was essentially normal. The complete haemogram revealed hemoglobin of $9.6 \mathrm{~g} / \mathrm{dL}$, white blood cell count 11,300/L, microcytic hypochromic anemia with no malaria parasite. The liver function test (LFT) revealed serum bilirubin of $12.3 \mathrm{gm} \%$ with conjugated and unconjugated being $6.3 \mathrm{gm} \%$ and $6 \mathrm{gm} \%$ respectively. The transaminases were substantially elevated i.e. AST \& ALT were 1530 and 1860 I.U. respectively. The International normalized ratio (INR) was also deranged to 1.3. Her HbsAg, HbeAg and IgM anti Hbc were positive with HBV DNA quantitative load of 5.2 lakhs I.U. per ml and $\mathrm{HBe} \mathrm{Ab}$ was negative. The ultrasound abdomen revealed features of acute hepatitis with gall bladder wall edema. The renal function test, blood sugar, serum amylase \& electrolytes, serum vitamin B12, D3, folic acid levels, urine \& blood culture, thyroid \& lipid profile, anti HCV, anti HIV antibody, IgM HAV antibody, IgM HEV antibody, autoimmune profile, serum copper \& ceruloplasmin level were all normal. The electrocardiogram and chest $\mathrm{x}$ ray were normal. The patient on third day of admission developed grade four hepatic encephalopathy and severe coagulopathy with INR of 2.6. She was managed in Intensive care unit with oral antiviral Entecavir 0.5 mg daily, in addition to standard treatment for acute liver failure including oral rifaxamin, ursodeoxycholic acid, lactulose, 1-ornithine-1-asparginase, 
$\mathrm{N}$-acetyl cystiene, Mannitol, raising of head end to 30 degrees and other supportive therapy. She responded to treatment and was out of encephalopathy in five days and her coagulation profile and liver function tests started improving as evidenced by decreasing trends of serum bilirubin and transaminases. She started accepting orally well with normal bowel and bladder habits and was discharged after ten days with serum bilirubin of $3.2 \mathrm{gm} \%$, AST \& ALT being 134 \& 158 I.U. and INR of 1.1 . She was regular in her follow up and after 2 weeks her liver function tests touched baseline and after three months there was seroconversion of HbeAg to $\mathrm{HBe} \mathrm{Ab}$, in addition to declining trend of HBV DNA quantitative levels i.e. 1.4 lakhs I.U. per ml, with normal Fibroscan score. After six months of initial illness, her HBV DNA was undetectable and her oral antiviral were stopped at this point of time. Now, six months more have elapsed and she is totally asymptomatic and HbeAg \& HbsAg are negative \& HBV DNA quantitative is undetectable, with normal Fibroscan score.

\section{Discussion}

In acute liver failure, patients are managed in the Intensive care unit for stabilization, controlling the complications arising from fulminant liver failure and as a bridge to liver transplantation. Cerebral edema occurs most in the acute liver failure and is the leading cause of mortality in these patients. The first aim is to prevent and manage intracranial hypertension (ICH). For it, minimal stimuli and head is elevated at $30^{\circ}$. Mannitol is used when the osmolarity is less than $320 \mathrm{mOsm} / \mathrm{L} \mathrm{[7].} \mathrm{The} \mathrm{induction} \mathrm{of}$ mild hypernatremia of 145 to $150 \mathrm{mmol} / \mathrm{L}$ can reduce the incidence and severity of $\mathrm{ICH}[8,9]$. Inducing therapeutic hypothermia $\left(33^{\circ} \mathrm{C}-35^{\circ} \mathrm{C}\right)$ may be beneficial for reducing splanchnic production of ammonia, restoring auto regulation of cerebral hemodynamics and decreasing oxidative metabolism in the brain [10]. Hyperventilation ( $\mathrm{PaCO} 2$ of 25 to $30 \mathrm{mmHg}$ ) is only indicated when there is acute neurologic deterioration (ICP> $20 \mathrm{mmHg}$ with evidence of increased cerebral blood flow. Spontaneous bleeding occurs in less than $10 \%$ of cases which is secondary to liver failure and increased consumption of procoagulant factors. In the absence of bleeding, and no need for invasive procedures [11], prophylactic correction of coagulopathy may not be beneficial and can even exacerbate volume overload. Consequently, use of plasma and vitamin $\mathrm{K}$ it is recommended only when an invasive procedure is necessary or when there is bleeding. Transplantation is one of the important and definitive treatment option for some specific causes of acute liver failure $[9,12]$ but it is not available for every patient. Only, less than $10 \%$ of liver transplantations are performed in patients with acute liver failure. The survival rates for these patients are always lower than those associated with elective liver transplantation due to infections during the first three months after surgery. The data is less clear for use of antiviral for acute fulminant hepatitis, because studies have been small and mostly retrospective in nature. The treatment of severe acute hepatitis $\mathrm{B}$ associated with liver failure remains unclear, because disparate results have been reported. At our centre for last three years we have used oral antiviral treatment for acute severe hepatitis B and results are very optimistic. Hence we used oral antiviral treatment in the present case with acute liver failure and were able to save precious life. The family was counseled for need of liver transplantation but they refused due to economic reasons.

\section{Conclusion}

The literature on treatment benefit are not clear in fulminant hepatitis B but immediate treatment is always justifiable when a patient presents with acute liver failure because of the maximum of reasonable expectation of benefit and the absence of major adverse events from therapy. More researches are required regarding use of oral antiviral in HBV related acute liver failure and acute severe hepatitis, so as to determine clearly their role in the management of above life threatening conditions. The use of antiviral in these conditions becomes more important in developing country like India where there is not only limited availability of liver transplantation but majority of needy patients cannot afford due to financial constraints.

\section{References}

1. Liang TJ, Hasegawa K, Rimon N, et al. (1991). A hepatitis B virus mutant associated whit an epidemic of fulminant hepatitis. N Engl J Med. 324(24):1705-1709.

2. Trepo CG, Robert D, Motin J, et al. (1976). Hepatitis B antigen (HBSAg) and/or antibodies (anti-HBS and anti-HBC) in fulminant hepatitis: Pathogenic and prognostic significance. Gut. 17:10-13.

3. Kitano K, Kobayashi H, Hanamura M, et al. (2006). Fulminant hepatitis after allogenic bone marrow transplantation caused by reactivation of hepatitis $\mathrm{B}$ virus with gene mutations in the core promotor region. Eur J Haematol. 77:255-258.

4. Khare S, Negi SS, Singh S, et al. (2012). Genetic analysis of precore/core and partial pol genes in an unprecedented outbreak of fulminant hepatitis $\mathrm{B}$ in India. Epidemiol Infec. 140(10):1823-189.

5. Rivero M, Crespo J, Fábrega E, et al. (2002). Apoptosis mediated by the Fas system in the fulminant hepatitis by hepatitis B virus. J Viral Hepatitis. 9(2):107-113.

6. Omata M, Ehata T, Yokosuka T, et al. (1991). Hepatitis B virus mutation and fulminant hepatitis. N Engl J Med. 324(24):16991704.

7. Umaña García P. (1990). Manejo de la falla hepática fulminante - Experiencia en la Fundación Santa Fe de Bogotá. Acta Med Col. 15(1).

8. Murphy N. (2004). The effect of hypertonic sodium chloride on intracranial pressure in patients with acute liver failure. Hepatology. 39(2):464-470.

9. Bernal W. (2008). Intensive care management of acute liver failure. Semin Liver Dis. 28(2):188-200.

10. Stravitz RT. (2009). Therapeutic hypothermia for acute liver failure. Crit Care Med. 37: 258-264.

11. Bernal W. (2013). Acute liver failure: Review article. N Engl J Med. 369:2525-2534.

12. Gómez Cabeza de Vaca V. (2012). Liver transplantation due to fulminant hepatic failure. Transplant P. 44: 2076-2077. 
This work is licensed under Creative Commons Attribution 4.0 License

To Submit Your Article Click Here: Submit Manuscript

DOI: $10.31579 / 2640-1053 / 069$
Ready to submit your research? Choose Auctores and benefit from:

$>$ fast, convenient online submission

$>$ rigorous peer review by experienced research in your field

$>$ rapid publication on acceptance

$>$ authors retain copyrights

$>$ unique DOI for all articles

$>$ immediate, unrestricted online access

At Auctores, research is always in progress.

Learn more auctoresonline.org/journals/cancer-research-and-cellulartherapeutics 